\title{
De gelegenheid te baat nemen?
}

\section{Criminaliteit in tijden van corona en sociale onthouding}

\author{
Edwin Kruisbergen, Marco Haas, Joanieke Snijders \& Ron Maas
}

Het coronavirus en de intelligente lockdown hebben tot grote persoonlijke en maatschappelijke schade geleid. Tegelijkertijd creëert de opgelegde sociale onthouding een vrij uniek, natuurlijk experiment dat interessante onderzoeksmogelijkheden biedt voor verschillende wetenschappelijke disciplines. Zo ook voor de sociale wetenschappen. Welke gevolgen hebben het gedwongen thuisblijven en de afgenomen mobiliteit bijvoorbeeld voor de criminaliteit? In dit artikel beschrijven we de ontwikkeling van de criminaliteit tijdens de lockdown.

De totale criminaliteitscijfers vertoonden aanvankelijk een forse daling, om na verloop van tijd weer terug te keren naar een vergelijkbaar niveau als we zagen voor de coronamaatregelen. Kijken we echter naar verschillende delictsoorten, dan zien we sterk afwijkende ontwikkelingen, met onder meer sterk gedaalde vermogenscriminaliteit en juist een forse toename van cybercriminaliteit. Deze veranderingen zijn goed te duiden vanuit een gelegenheidstheoretisch perspectief. De duiding van de ontwikkeling van het aantal gevallen van huiselijk geweld lijkt vooralsnog uitdagender; de alom gevreesde forse stijging komt niet terug in de politiecijfers. Tot slot lijkt er in de populatie verdachten van een woninginbraak een verschuiving zichtbaar; zo is bijvoorbeeld de uitkeringsafhankelijkheid onder deze deelcategorie verdachten toegenomen. Onder de populatie slachtoffers van woninginbraak lijken geen grote veranderingen te zijn opgetreden.

\section{Introductie}

Medio maart begon in Nederland een unieke periode van sociale onthouding, met een sterk afnemende mobiliteit als gevolg. ${ }^{1}$ Niet lang daarvoor was er echter nog niet veel bijzonders aan de hand, zo was bij velen de gedachte. Het COVID-19virus leek een beetje op een normale griep, zo werd verondersteld, en een grote verspreiding binnen Nederland werd niet direct voorzien. In maart kantelt het beeld echter. Eind februari wordt de eerste Nederlandse besmetting met 'corona' vastgesteld, een week later volgt de eerste als zodanig aangemerkte coronadode. Op 6 maart (week 10) adviseert het RIVM mensen in Noord-Brabant die klachten hebben sociaal contact te beperken. De week daarna (week 11) wordt het heersende beeld grimmiger en nemen de autoriteiten meer verregaande maatregelen. Op 9 maart is er het advies geen handen meer te schudden. Op 12 maart wordt iedereen gevraagd thuis te werken als dat kan, mensen met klachten wordt gesommeerd thuis te blijven en evenementen met meer dan honderd mensen 
worden afgelast. Zondag 15 maart (net voordat week 12 begint) volgt de aankondiging van de sluiting van scholen en van onder meer de horeca en wordt opgeroepen tot social distancing, waarbij als richtlijn anderhalve meter afstand geldt. Op 23 maart (week 13) wordt het belang van sociale onthouding nog eens onderstreept en wordt de intelligente lockdown afgekondigd. Bovenop de genoemde maatregelen komt het verbod op de uitoefening van contactberoepen. Verder worden alle evenementen met een vergunnings- en meldplicht verboden en komt er een samenscholingsverbod. Vanaf week 20 volgen er versoepelingen. Op 11 mei gaan de basisscholen weer open, hoewel aanvankelijk slechts gedeeltelijk, 1 juni volgt het middelbaar onderwijs en vanaf dezelfde dag mogen horeca en (sommige) culturele instellingen hun deuren weer openen, onder de voorwaarde dat het aantal bezoekers de dertig niet overschrijdt.

Welke gevolgen hebben het gedwongen thuisblijven en de afgenomen mobiliteit voor de criminaliteit? In dit artikel beschrijven we de ontwikkeling van de criminaliteit tijdens de lockdown. Hieronder bespreken we in paragraaf 2 wat criminologische (en aanverwante) theorieën en eerder empirisch onderzoek ons leren over de ontwikkeling van criminaliteit ten tijde van exceptionele sociale omstandigheden. Daarna lichten we in paragraaf 3 de data toe die we gebruiken voor onze verkennende analyse. De empirische ontwikkeling van de criminaliteit ten tijde van de lockdown analyseren we in paragraaf 4 . In paragraaf 5 vatten we de empirische resultaten nog eens samen en verkennen we de inzichten en lessen die de resultaten ons bieden.

\section{Theoretische en empirische inzichten uit de criminologie}

De lockdown plaatst de samenleving in een uitzonderlijke situatie. Zouden we in criminologische (en aanverwante) theorieën inzichten of een kader kunnen vinden dat ons helpt de ontwikkeling van criminaliteit in tijden van opgelegde sociale onthouding te duiden? En wat leert eerder empirisch onderzoek over de relatie tussen criminaliteit en sociale ontwrichting? In de conclusie van dit artikel komen we kort terug op met name de theoretische inzichten.

\subsection{Theoretische inzichten}

Criminologische theorievorming kan vanuit verschillende vertrekpunten plaatsvinden. Zo kunnen oorzaken van crimineel gedrag worden gezocht in maatschappelijke structuren en achterstand of in conflicten tussen groeperingen of klassen. Anderen kiezen juist het individu als vertrekpunt en wijzen naar bijvoorbeeld psychologische of biologische kenmerken als verklarende factoren van crimineel gedrag. ${ }^{2}$ Het individu heeft ook een centrale plaats in de sociale bindingstheorie van Hirschi (1969). ${ }^{3}$ Toch had deze bekende criminologische denker een heel ander perspectief dan veel van zijn tijdgenoten. Hij ging er namelijk van uit dat de mens in het algemeen is geneigd tot criminaliteit en dat dus niet crimineel 
gedrag, maar juist het uitblijven daarvan moest worden verklaard. Mensen zien af van criminaliteit wanneer zij in voldoende mate sociale bindingen hebben met de conventionele orde. Die bindingen zijn er op verschillende niveaus. Zo zal iemand met een positieve band met het eigen gezin, met school en een positieve houding tegenover de samenleving, meer baat hebben bij normconform gedrag dan iemand die die binding in mindere mate heeft. Later brachten Gottfredson en Hirschi (1990), ${ }^{4}$ in een 'algemene theorie van criminaliteit', normafwijkend gedrag terug tot één centrale factor, een gebrek aan zelfbeheersing. ${ }^{5}$

Een ander vertrekpunt vinden we in de gelegenheidstheorie. Deze benadering legt in tegenstelling tot veel andere benaderingen niet de nadruk op persoonlijke daderkenmerken, maar zoekt juist naar factoren die gelegenheid bieden voor criminaliteit. De kern van deze benadering valt samen met het gezegde 'de gelegenheid maakt de dief'. De conceptuele eenvoud is voor sommigen een sterk punt, maar staat voor anderen gelijk aan a-theoretisch simplisme. ${ }^{6}$

Een bekende gelegenheidstheorie is de routine-activiteitentheorie. Cohen en Felson stellen dat de meeste criminele activiteiten de samenkomst in ruimte en tijd vereisen van drie omstandigheden: geschikte doelwitten, gemotiveerde daders en de afwezigheid van adequaat toezicht. ${ }^{7}$ Terugdringing van (de samenkomst van) deze omstandigheden zal tot een afname van criminaliteit leiden. Zo zal volgens deze benadering beter hang- en sluitwerk op woningen (minder geschikte doelwitten) of een grotere aanwezigheid van bewoners, buren of rechtshandhavers (toezichthouders) leiden tot minder woninginbraken, ook als het aantal potentiele inbrekers gelijk blijft.

De gelegenheidstheoretische benadering ligt aan de basis van situationele criminaliteitspreventie, waarbij criminaliteitsbevorderende omstandigheden - de mogelijkheid tot het plegen van een misdrijf - zo veel mogelijk worden weggenomen. De situationele criminaliteitspreventie zien we terug in de verschillende barrièremodellen die in de loop der jaren zijn ontwikkeld. In een barrièremodel wordt voor een specifiek type delict stapsgewijs beschreven wat er nodig is voor de totstandkoming van dat delict, om vervolgens per stap na te gaan welke drempel - barrière - opgeworpen kan worden om de totstandkoming te verhinderen. ${ }^{8}$

Tot slot is er ook theorievorming die zich specifiek richt op natuurrampen, die, net als een pandemie, tot sociale ontwrichting kunnen leiden. Daarbij zijn er volgens Zahran e.a. twee smaken. ${ }^{9}$ Eén stroming stelt dat in een samenleving die aan een ramp is blootgesteld sociale bindingen en pro-sociaal gedrag toenemen, met uiteindelijk een daling van de criminaliteit als gevolg. Hierbinnen is het werk van Fritz van belang. ${ }^{10}$ Die beschreef in een door Robert Merton geredigeerde bundel dat gedrag na een ramp gekenmerkt wordt door altruïsme en gericht op

4 Gottfredson \& Hirschi 1990.

$5 \quad$ Kleemans e.a. 2007; Van Swaaningen \& Schuilenburg 2018.

6 Clarke 2012.

7 Cohen \& Felson 1979.

8 Zo zijn er barrièremodellen ontwikkeld voor de preventie van mensenhandel, kinderporno, productie van synthetische drugs, hennepteelt en mobiel banditisme.

9 Zahran e.a. 2009.

10 Fritz 1969. 
het herstel van de gemeenschap. Dat zou samenhangen met onder meer het voor iedereen zichtbare lijden, waardoor empathie toeneemt, en het als gevolg van de ramp wegvallen van sociale scheidslijnen (iedereen lijdt immers). Een andere stroming wijst er juist op dat een natuurramp sociale cohesie en mechanismen van sociale controle afbreekt, waardoor criminaliteit stijgt. ${ }^{11}$ Wij merken hierbij op dat er belangrijke verschillen zijn tussen natuurrampen zoals grote overstromingen enerzijds en de coronapandemie anderzijds. Natuurrampen gaan nogal eens gepaard met de (gedeeltelijke) vernietiging van de fysieke omgeving, fysieke isolatie en de onbereikbaarheid voor hulpdiensten. Bij de coronapandemie is daar geen sprake van. Ook voltrekken pandemieën zich doorgaans wat geleidelijker dan natuurrampen. ${ }^{12}$ Ontwrichting van het dagelijks leven, gedwongen thuisblijven/ gebrek aan mobiliteit en sociale isolatie zijn daarentegen weer overeenkomsten.

\subsection{Empirisch onderzoek}

Er is eerder empirisch onderzoek verricht naar de ontwikkeling van criminaliteit in tijden van natuurrampen en andere exceptionele omstandigheden. ${ }^{13}$

Ashby heeft in een vroege 'coronastudie' gekeken naar criminaliteitscijfers. ${ }^{14} \mathrm{Hij}$ gebruikt daarvoor data uit zestien grote steden in de Verenigde Staten. Per stad en per criminaliteitstype toetst hij of de cijfers afwijken van de 'natuurlijke' variatie in die cijfers die er was voor corona. Verschillende delicten, maar ook de verschillende steden, laten verschillende uitkomsten zien. In sommige steden is het aantal woninginbraken significant afgenomen. Ook diefstal van motorvoertuigen daalt in sommige steden, maar stijgt juist in enkele andere steden.

Welke veranderingen treden erop bij huiselijk geweld? Peterman en anderen noemen, op basis van literatuur, negen factoren via welke natuurrampen en pandemieën tot (meer) geweld tegen vrouwen en kinderen ${ }^{15}$ kunnen leiden: stress als gevolg van economische onzekerheid, sociale isolatie, maatschappelijke onrust en instabiliteit, blootstelling aan uitbuitingsrelaties als gevolg van demografische veranderingen (veel sterfte onder ouders leidt bijvoorbeeld tot grotere afhankelijkheid van kinderen), minder toegankelijke (eerstelijns) hulpverlening, minder mogelijkheden om een partner te verlaten, virusspecifiek geweld of uitsluiting, bijvoorbeeld vanwege toegeschreven schuld aan een virusuitbraak, blootstelling aan geweld en uitbuiting bij hulpverlening, geweld tegen hulpverleners. ${ }^{16}$ In tegenstelling tot zorgen die ook beleidsmakers in de VS daaromtrent hebben geuit, laten de analyses van Ashby echter geen eenduidige verandering zien in het aantal gevallen van wat wij waarschijnlijk 'huiselijk geweld' zouden noemen. ${ }^{17}$

\section{Zahran e.a. 2009.}

Ashby 2020.

We bespreken enkele studies. Dit biedt zeker geen volledig overzicht. Geïnteresseerden kunnen mede via de besproken titels andere studies raadplegen.

Ashby 2020.

Ook mannen kunnen slachtoffer zijn van huiselijk geweld.

Peterman e.a. 2020.

Ashby (2020) kijkt hier naar de 'serious assaults in residences'. Deze categorie is niet per se gelijk aan huiselijk geweld ('domestic violence'). 
Ook andere studies gaan in op de ontwikkeling van criminaliteit tijdens en na natuurrampen. Weitzman en Behrman gebruikten onder meer data uit gezondheidsonderzoek in een analyse van partnergeweld voor en na de aardbeving op Haïti in 2010. Zij vonden dat blootstelling aan de vernietiging als gevolg van de aardbeving wel degelijk de kans verhoogde op slachtofferschap van zowel lichamelijk als seksueel partnergeweld. ${ }^{18}$ De aardbeving hing ook samen met andere veranderingen binnen gezinnen, zoals meer controlerend gedrag bij mannen en verminderde arbeidsparticipatie en een slechtere toegang tot sociale hulp (bezoek vrienden) bij vrouwen.

Zahran en anderen onderzochten de relatie tussen natuurrampen en criminaliteit in Florida. Deze Amerikaanse staat wordt regelmatig blootgesteld aan verschillende van die rampen, zoals stormen, overstromingen en bosbranden. Hun artikel beschrijft een significant verlagend effect op vermogens- en geweldscriminaliteit en een significant verhogend effect op huiselijk geweld. ${ }^{19}$

Ten slotte kunnen ook bepaalde sportevenementen worden gezien als een exceptionele sociale omstandigheid - als een gebeurtenis die in potentie de routineactiviteiten van veel mensen verandert. ${ }^{20}$ Piquero e.a. onderzochten of geweldsmisdrijven, vermogensmisdrijven en seksuele uitbuiting toenamen tijdens de Formule 1 Gran Prix (autoraces) van 2018 in Austin, Texas. Zij vonden voor geen van deze misdrijven een significante toename. ${ }^{21}$ Ashby beschrijft overigens hoe, net zoals geldt voor studies naar natuurrampen, verschillende studies naar criminaliteit tijdens grote (sport)evenementen verschillende uitkomsten laten zien. ${ }^{22}$

\section{Onze analyses: afbakening en gebruikte data}

Onze primaire aandacht richt zich op de ontwikkeling van de criminaliteit tijdens de opgelegde sociale onthouding. Daarvoor gebruiken we politiegegevens. Die politiegegevens betreffen geregistreerde criminaliteit. Als bron van de gegevens wordt gebruikgemaakt van de Basisvoorziening Handhaving (BVH), het bedrijfsprocessensysteem van de Nederlandse politie waarin onder meer alle incidenten en misdrijven die bekend zijn bij de politie worden geregistreerd. Dit kan naar aanleiding van een aangifte zijn of op een andere manier door de politie worden geconstateerd. Medewerkers van de politie en het ministerie van Justitie en Veiligheid hebben, om zicht te krijgen op de ontwikkeling van criminaliteit in deze bijzondere periode, een instrument ontwikkeld dat gebruikmaakt van de BVH; de

21 Piquero e.a. 2019.

22 Ashby 2020. 
Corona Crime Change Monitor (CCCM). ${ }^{23}$ Die CCCM gebruiken wij hier voor de analyse van de ontwikkeling binnen een aantal delicttypen. ${ }^{24}$

Daarnaast gaan we ook na of de populaties van verdachten en slachtoffers zijn veranderd in deze periode. Voor een zicht op achtergrondkenmerken van verdachten en slachtoffers worden BVH-gegevens geleverd aan het Centraal Bureau voor de Statistiek (CBS). Het CBS vult de verdachten- en slachtoffergegevens dan aan met een aantal vooraf bepaalde variabelen en stuurt geaggregeerde data vervolgens terug. Die geaggregeerde data hebben wij gebruikt.

Hieronder lichten we een en ander nader toe.

\subsection{Geregistreerde misdrijven en overlast}

Voor de analyse van de ontwikkeling van de criminaliteit gebruiken we dus gegevens over geregistreerde misdrijven afkomstig uit de CCCM. De makers van de CCCM hebben ervoor gekozen om een overzichtelijk aantal delicten op te nemen, delicten waarvan verwacht kon worden dat deze mogelijk een ontwikkeling zouden laten zien als gevolg van de coronapandemie en de lockdown. Voor dit artikel gebruiken wij de meeste van die delicttypen. Behalve het totale aantal geregistreerde misdrijven gaat het om:

- geregistreerde 'traditionele' vermogensmisdrijven:

- woninginbraken (voltooid);

- zakkenrollerij;

- fietsendiefstal;

- babbeltrucs;

- online misdrijven, dit betreft zowel cybercrime als vormen van fraude met een online component; ${ }^{25}$

- huiselijk geweld.

Daarnaast kijken we naar overlast. Overlastmeldingen zijn meegenomen vanwege een mogelijk verband met het gedwongen thuisblijven van veel mensen.

Voor bovengenoemde indicatoren worden weekcijfers geanalyseerd, vanaf week 1 (30 december 2019 - 5 januari 2020) tot en met week 30 (20 juli - 26 juli 2020), tien weken na de eerste versoepeling van de maatregelen. Hierin zijn vier periodes te onderscheiden:

- $\quad$ week 1-9: de weken voor de maatregelen;

23 Marco Haas, Joanieke Snijders en Ron Maas zijn betrokken bij het ontwerp en de ontwikkeling van de CCCM.

24 De data in de CCCM betreffen ruwe data. Mogelijk gaat het in enkele gevallen over zaken die later in het proces afvallen (aangifte wordt bijvoorbeeld ingetrokken). De gegevens kunnen daarmee afwijken van latere publicaties waarin de politie meer definitieve gegevens naar buiten brengt over 'geregistreerde misdrijven' (en waarop de data in de paragraaf 'Verdachten en slachtoffers' is gebaseerd).

25 Onder cybercrime worden hier verstaan delicten die worden gepleegd mét en gericht zijn óp een ICT-middel. Het gaat dan bijvoorbeeld om (D)DoS-aanvallen, malware en ransomware. Bij fraude met een online component gaat het om gedigitaliseerde criminaliteit, dat wil zeggen gepleegd met een ICT-middel, maar niet op een ander ICT-middel gericht. Voorbeelden zijn phishing, marktplaatsfraude en vriend-in-noodfraude via bijvoorbeeld WhatsApp. 
- week 10-11: de weken met beperkte maatregelen, zoals adviezen over hygiene;

- week 12-22: de weken met de striktste maatregelen, zoals het sluiten van scholen en horecagelegenheden in week 12 en de door het kabinet genoemde 'intelligente lockdown';

- vanaf week 20: vanaf 11 mei werden enkele maatregelen versoepeld, zoals de (gedeeltelijke) opening van basisscholen.

Cijfers uit deze periode(s) vergelijken we steeds met cijfers over de dezelfde weken in 2019. Zo corrigeren we enigszins voor eventuele seizoensinvloeden en wordt het mogelijk om te beoordelen of de cijfers voor 2020 echt een andere trend laten zien dan die voor 2019.

\subsection{Verdachten en slachtoffers}

Tevens gaan we via een hele grove analyse na of de populaties van verdachten en slachtoffers zijn gewijzigd ten tijde van de lockdown. Dat doen we alleen voor verdachten en slachtoffers van woninginbraken. De gegevens over verdachten en slachtoffers waren pas beschikbaar zeer kort voor de deadline die gold voor dit themanummer. We hebben daarom een keuze gemaakt voor verdachten en slachtoffers van één delict. Daarbij is gekozen voor woninginbraak, omdat dat delict vaak genoeg voorkomt om enigszins zinvol een onderscheid te kunnen maken naar achtergrondkenmerken van verdachten en slachtoffers. Bovendien is het een delict dat wat betreft ernst heel grofweg tot de middencategorie gerekend kan worden.

Zoals eerder genoemd is de informatie over achtergrondkenmerken van verdachten en slachtoffers afkomstig van het CBS. Voor dit artikel hebben we gebruikgemaakt van de kenmerken leeftijdscategorie, opleidingsniveau, geslacht, uitkeringsafhankelijkheid (WW of bijstand), samenstelling huishouden en stedelijkheid van de woongemeente.

Gegevens over verdachten en slachtoffers zijn beschikbaar in maand- en niet in weekcijfers. Verder komen deze gegevens later binnen dan de data over geregistreerde misdrijven. Omdat de cijfers van mei nog niet beschikbaar waren, gebruiken we voor verdachten en slachtoffers de gegevens voor april. Het voordeel van april is dat deze gehele maand de zwaardere coronamaatregelen van kracht waren. We vergelijken de verdeling van verdachten en slachtoffers over de genoemde kenmerken in april 2020 met de verdeling over die kenmerken in dezelfde maand in de drie voorafgaande jaren (2017, 2018 en 2019).

\subsection{Pleegdatum en registratiedatum}

Bij de data over delicten geldt de datum dat de politie van het delict kennisnam als uitgangspunt. Bij de gegevens over verdachten en slachtoffers wordt gekeken naar de pleegdatum van het delict. Bij beide benaderingen is sprake van een naijleffect: de registraties kunnen nog worden bijgewerkt en voor de data die op pleegdatum zijn geselecteerd (verdachten/slachtoffers) geldt dat in sterkere mate. Tot slot een opmerking over het bereik van de analyses. Op het moment van schrijven (eind juli) zijn de gebruikte data pas net binnen. Bovendien zijn nog veel 
Figuur 1 Totaal aantal geregistreerde misdrijven in 2019 en 2020, week $12 \mathrm{t} / \mathrm{m}$ 22

Totaal misdrijven week 12-22

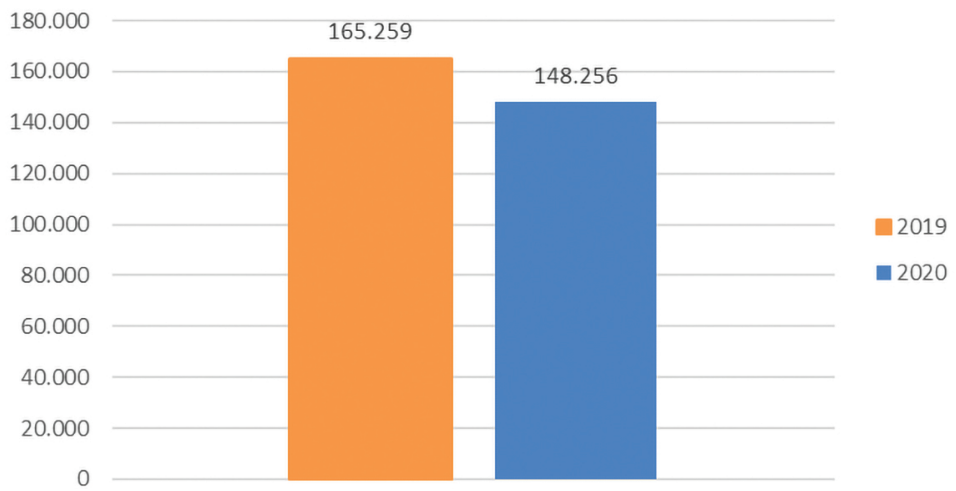

Bron: Corona Crime Change Monitor

coronamaatregelen van kracht (hoewel versoepelingen inmiddels elkaar opvolgen); we zitten dus nog midden in de tijd die we onderzoeken. Onze analyses zijn daarom vooral verkennend. $\mathrm{Na}$ verloop van tijd zullen wat diepere analyses mogelijk zijn.

\section{Empirische resultaten}

In deze paragraaf gaan we achtereenvolgens in op de ontwikkeling van de criminaliteit ten tijde van de lockdown, de ontwikkeling van het aantal overlastmeldingen, en eventuele veranderingen in de populatie van verdachten en slachtoffers van woninginbraken.

\subsection{Ontwikkeling van de geregistreerde criminaliteit}

- Totaal geregistreerde misdrijven

Figuur 1 toont het totale aantal geregistreerde misdrijven in de weken 12 tot en met 22 (peildatum 1 juni), in zowel 2019 als 2020. We kijken specifiek naar deze periode, omdat in de genoemde weken (in 2020) de strengste maatregelen van kracht waren. In 2020 ligt het aantal geregistreerde misdrijven in de genoemde periode ongeveer $10 \%$ lager dan dezelfde periode een jaar daarvoor (148.256 registraties in 2020 tegenover 165.259 registraties in 2019).

Figuur 2 toont de weektotalen voor geregistreerde misdrijven voor de periode week 1 tot en met week 30, wederom voor 2019 en 2020. We beginnen hier bij week 1, omdat we vooral willen zien wat de strengere coronamaatregelen 
Figuur 2 Totaal aantal geregistreerde misdrijven in 2019 en 2020, weektotalen, week $1 \mathrm{t} / \mathrm{m} 30$ en gemiddelde week 1-9 van 2020

Totaal misdrijven week 1-30

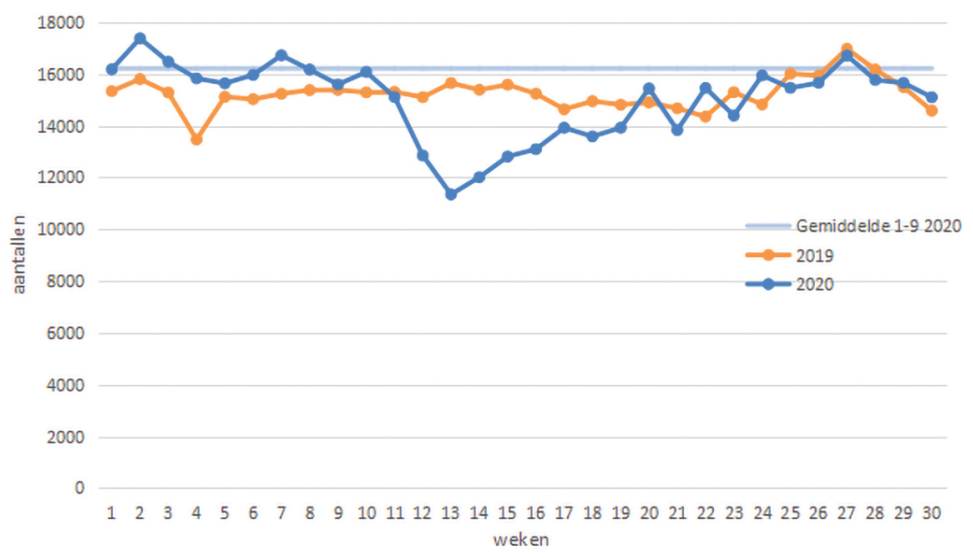

Bron: Corona Crime Change Monitor

mogelijk voor invloed hebben gehad op de criminaliteitsontwikkeling en dan is het zinvol om ook de voorafgaande periode in ogenschouw te nemen. Deze grafiek geeft daarmee een preciezer beeld van wat nu de potentiële gevolgen zijn geweest van de maatregelen. ${ }^{26}$

In de weken voor de hygienemaatregelen (week 1-9) lag het gemiddelde aantal geregistreerde misdrijven iets boven het niveau van dezelfde weken in 2019, grofweg 16.200 registraties gemiddeld per week in 2020 tegen ongeveer 15.100 gemiddeld per week in 2019. Ook in de weken 10 en 11 liggen de aantallen redelijk dicht bij elkaar. In week 12, de eerste week van de strengere maatregelen, zoals het sluiten van de scholen en de horeca, daalt het aantal geregistreerde misdrijven echter sterk, tot grofweg 12.850 (in 2019 in dezelfde week: ongeveer 15.100). In week 13 werd in Nederland de intelligente lockdown afgekondigd. Deze week laat een verdere daling zie; het totaal aantal geregistreerde misdrijven daalt tot ongeveer 11.350. Dit is een afname met $30 \%$ ten opzichte van het gemiddelde van de weken voorafgaand aan de maatregelen (week 1-9) en een afname van $27 \%$ ten opzichte van dezelfde week een jaar eerder.

Na week 13 (2020) zien we echter een stijging van het aantal bij de politie geregistreerde misdrijven, een stijging die zich ruwweg doorzet tot week 20 (met een

26 De weekcijfers tonen wanneer precies de verschillen tussen de beide jaren ontstaan en wanneer die groter of juist kleiner worden. Verder maken weekcijfers het mogelijk om te zien of een bepaalde ontwikkeling, zoals die bijvoorbeeld te zien is vanaf met name week 12, mogelijk al eerder is ingezet (dus voor de lockdown). 
kleine dip in week 18). In week 20 worden circa 15.440 misdrijven door de politie geregistreerd, een verschil van nog maar $-5 \%$ met het gemiddelde van de weken 1-9 van 2020. In week 20 (de week van de eerste versoepeling van de maatregelen) komt het cumulatieve aantal geregistreerde misdrijven voor het eerst sinds de genomen maatregelen op een hoger niveau dan in 2019.

Het totaalbeeld is dus vrij helder. Sinds de lockdown is het wekelijks aantal geregistreerde misdrijven vrij sterk en abrupt gedaald. Na enkele weken steeg dat aantal weer, om uiteindelijk op een vergelijkbaar niveau uit te komen als een jaar eerder.

Het totale volume van geregistreerde misdrijven laat dus grote veranderingen zien, in ieder geval tijdelijk. Is er ook een verschuiving waar te nemen in de aard van de misdrijven? Ja die is er zeker, zoals hieronder wordt weergegeven.

\section{- Vermogensmisdrijven}

Binnen deze analyse wordt voor de ontwikkeling van vermogensmisdrijven gekeken naar (voltooide) woninginbraken, fietsdiefstallen en zakkenrollerij, delicten die afhankelijk zijn van de mobiliteit van potentiële slachtoffers. Doordat door de maatregelen mensen meer aan huis gebonden zijn, is er in beginsel minder gelegenheid voor het plegen van deze misdrijven. Daarnaast wordt ook het delict 'babbeltruc' als indicator meegenomen, omdat de vrees was dat daders misbruik zouden maken van onzekere en/of onwetende (oudere) slachtoffers in combinatie met grote onzekerheid over het virus en de aanpak daarvan. ${ }^{27}$ Figuur 3 toont de totale aantallen van deze vier vermogensmisdrijven in de weken 12 tot en met 22, voor zowel 2019 als 2020 .

Figuur 3 Geregistreerde vermogensmisdrijven, vier soorten, in 2019 en 2020, week $12 \mathrm{t} / \mathrm{m} 22$

Totaal vermogensmisdrijven week 12-22

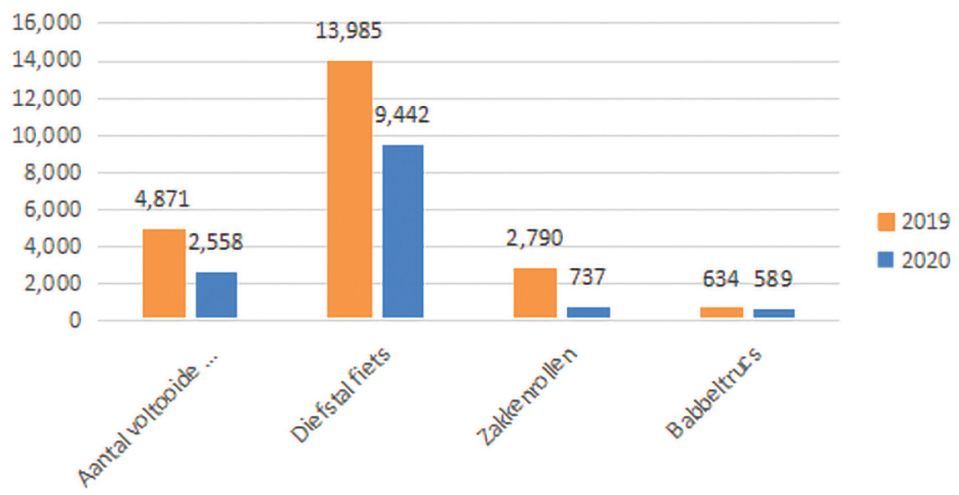

Bron: Corona Crime Change Monitor 
Het totale aantal in de weken 12-22 ligt voor alle vier de delicten in 2020 lager dan in 2019. Voor fietsendiefstal (-32\%), woninginbraken (-47\%) en zakkenrollerij (-74\%) liggen die aantallen fors lager, met afnames van respectievelijk een derde, de helft en driekwart. Vanuit het gelegenheidstheoretische perspectief van de routine-activiteitentheorie is deze ontwikkeling goed te begrijpen. Die theorie stelt dat criminaliteit drie elementen vereist: geschikte doelwitten, gemotiveerde daders en de afwezigheid van adequaat toezicht. Als gevolg van de intelligente lockdown zijn er minder geschikte doelwitten; er worden waarschijnlijk minder fietsen gestald op plaatsen waar deze makkelijk ontvreemd kunnen worden, zoals stations en in binnensteden, en er zijn veel minder drukbezochte plaatsen waar zakkenrollers doorgaans op afkomen (bovendien is anderhalve meter afstand een omstandigheid die het zakkenrollers ook moeilijker maakt). Verder staan heel veel woningen onder actief 'toezicht'; de bewoners werken immers vaak thuis.

Ook het aantal babbeltrucs ligt in deze periode lager dan in het voorafgaande jaar, maar die afname is minder indrukwekkend (-7\%). Deze daling is contrair aan wat werd gevreesd. Bij dit type delict zijn misschien verschillende mechanismen werkzaam geweest tijdens de lockdown. Zo is het goed mogelijk dat enerzijds sommige daders inderdaad gebruik hebben gemaakt van het coronavirus om bij slachtoffers binnen te komen, waarover in de media ook berichten zijn verschenen. ${ }^{28}$ Anderzijds heeft coronagerelateerde fraude zich deels juist online afgespeeld. ${ }^{29}$ Bovendien kan de gevraagde sociale onthouding ertoe hebben geleid dat potentiële slachtoffers extra voorzichtig waren om mensen binnen te laten (en/of dat daarop is geanticipeerd door potentiële daders).

Als in een verdieping wordt gekeken naar de wekelijkse ontwikkeling van het aantal (voltooide) woninginbraken (figuur 4), is duidelijk dat in week 12 het aantal gevallen sterk daalt, namelijk naar circa 284 woninginbraken, een verschil van $-55 \%$ ten opzichte van het gemiddelde van week 1-9. Vanaf dezelfde week 12 ontstaat ook een groot verschil ten opzichte van dezelfde periode in 2019. Vervolgens blijft het aantal voltooide inbraken wekenlang op een substantieel lager niveau dan in dezelfde week een jaar eerder (voor de periode week 12 tot week 22 geldt een totale afname van 47\%). Vanaf week 21, een week na de eerste versoepelingen van de maatregelen, gaat het aantal voltooide inbraken in 2020 echter weer iets meer richting het niveau van 2019, een trend die zich ook in de weken daarna doorzet.

\section{- Online misdrijven}

Waar de meer traditionelere vermogenscriminaliteit in de weken 12-22 van 2020 in vergelijking tot de dezelfde periode in 2019 dus een (zeer sterke) afname laat zien, is het beeld bij online misdrijven volledig anders (figuur 5). Allereerst merken we op dat online misdrijven zowel in 2019 als in 2020 een zeer grillig verloop

28 www.limburger.nl/cnt/dmf20200616_00164419/ggd-waarschuwt-voor-corona-babbeltrucs.

29 Zo kunnen daders phishingmails sturen waarin wordt medegedeeld dat een bankpas moet worden vervangen, hetgeen vanwege de coronapandemie niet via bankbezoek zou kunnen (www.politie.nl/nieuws/2020/mei/8/04-aanhoudingen-in-phishingzaak-coronacrisismisbruikt.html). Een ander voorbeeld is oplichting met mondkapjesverkoop. 
Figuur 4 Geregistreerde voltooide woninginbraken in 2019 en 2020, weektotalen, week $1 \mathrm{t} / \mathrm{m} 30$

Voltooide woningbraken week 1-30

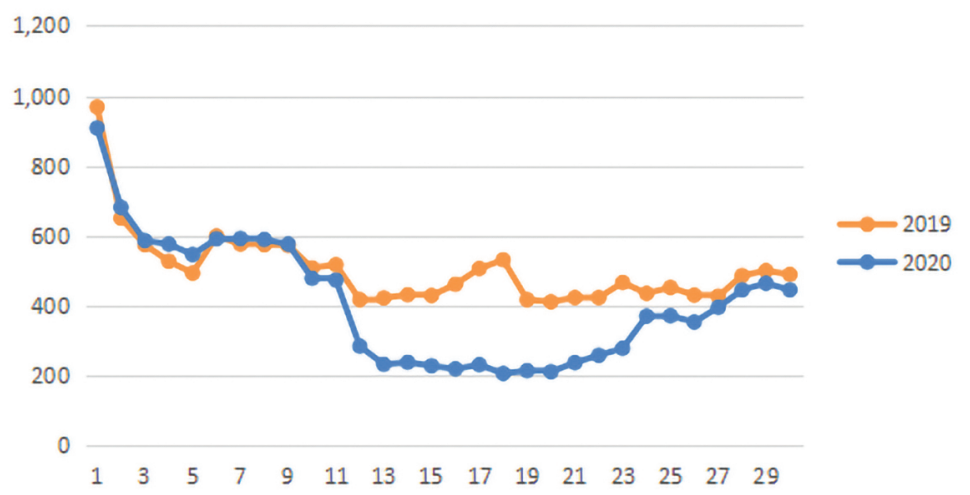

Bron: Corona Crime Change Monitor

laten zien. Duidelijk is echter wel dat in de periode van de lockdown het aantal online misdrijven zeer sterk is toegenomen.

In de weken 12-22 van 2020 lag het totale aantal bij de politie geregistreerde online misdrijven 96\% hoger dan in dezelfde periode in 2019 (18.697 in 2020, 9.563 in 2019). Het totale aantal online misdrijven is dus grofweg verdubbeld.

Figuur 6 geeft de wekelijkse ontwikkeling weer. Daarin zien we allereerst dat de wekelijkse aantallen al in week 9 en 10 flink hoger lagen dan in dezelfde weken van 2019. De stijging van het aantal online misdrijven start iets later dan de afkondiging van de 'intelligente lockdown' (week 13). Waar de registraties in de weken 12-14 rond of onder het niveau van 2019 liggen, begint het aantal online misdrijven na week 14 sterk te stijgen tot ruim boven het niveau van dezelfde weken in 2019. Met name in de laatste vier weken van mei 2020 is het aantal online misdrijven explosief gestegen. In de laatste week van mei (week 22) lag het aantal geregistreerde online misdrijven met 2.627 bijna vijf keer hoger dan het aantal een jaar eerder (559) en $104 \%$ hoger dan het gemiddelde van de weken 1-9 van 2020.

Vooral in de periode week 13-22 laten de twee lijnen ook een afwijkende trend zien; voor 2019 is die trend dalend, voor 2020 is die stijgend. ${ }^{30}$ Hiermee wijkt de trendlijn van online misdrijven ook duidelijk af van de trendlijn van woninginbraken en het totale aantal geregistreerde misdrijven. Vanaf week 23 groeien de lijnen weer naar elkaar toe, mede dankzij een sterke stijging vanaf die week in 2019. Zoals gezegd is het verloop van het aantal online misdrijven nogal grillig, zowel in 2019 als in 2020. Dat noopt wel tot enige terughoudendheid bij de interpretatie van de gepresenteerde cijfers van week tot week (beter is het trendmatig 
Figuur 5 Geregistreerde online misdrijven in 2019 en 2020, week 12 t/m 22 totaal online misdrijven week 12-22

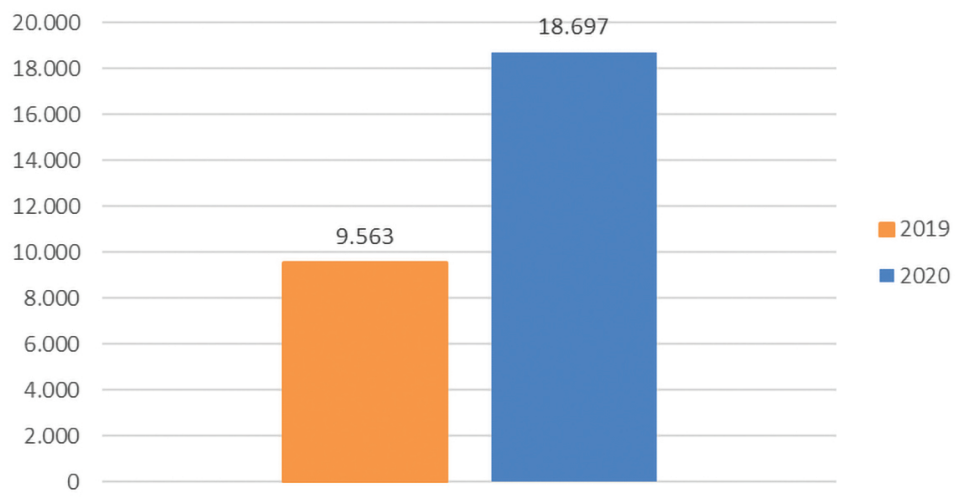

Bron: Corona Crime Change Monitor

te kijken) en vraagt ook om nadere analyse, bijvoorbeeld van niet-coronagerelateerde factoren die van invloed zijn op het aantal online misdrijven (en/of een statistische toets van de omvang van de mogelijk aan de lockdown toe te schrijven variatie). Die analyses liggen echter buiten het bereik van dit artikel. Dat voorbehoud gemaakt hebbend, vragen we ons af hoe de ontwikkeling van het aantal online misdrijven in 2020, die grotendeels samenvalt met de periode van de lockdown, is te interpreteren.

Ook bij online misdrijven biedt de routine-activiteitentheorie daarvoor een nuttig perspectief. Vanwege het min of meer gedwongen thuisblijven is het online verkeer vanaf thuis waarschijnlijk sterk toegenomen: thuiswerken, online winkelen en boodschappen doen, online contacten onderhouden met vrienden en familie, en online vermaak. Het leven speelt zich dus meer online af (ook voor mensen die er minder bedreven in zijn), wat tot meer geschikte doelwitten heeft geleid. Mogelijk hebben daders daar gebruik van gemaakt. Een interessante vraag daarbij is of bestaande cybercrimedaders actiever zijn geworden of dat de lockdown tot toestroom van nieuwe daders heeft geleid (of beide), dat wil zeggen daders die voorheen niet online actief waren. ${ }^{31}$

\section{- Huiselijk Geweld}

In verband met het min of meer opgelegde thuisblijven is verschillende keren de verwachting uitgesproken dat de spanningen binnen huishoudens zouden oplopen, met een gevreesde toename van huiselijk geweld als gevolg. Behalve dat leden van een huishouden (en dus ook daders en slachtoffers van huiselijk geweld) meer aan huis gebonden zijn, kan ook economische onzekerheid binnen een huishouden tot meer stress en meer geweld hebben geleid. De Verenigde 
Figuur 6 Geregistreerde online misdrijven in 2019 en 2020, weektotalen, week $1 t / m 30$

\section{Online misdrijven week 1-30}

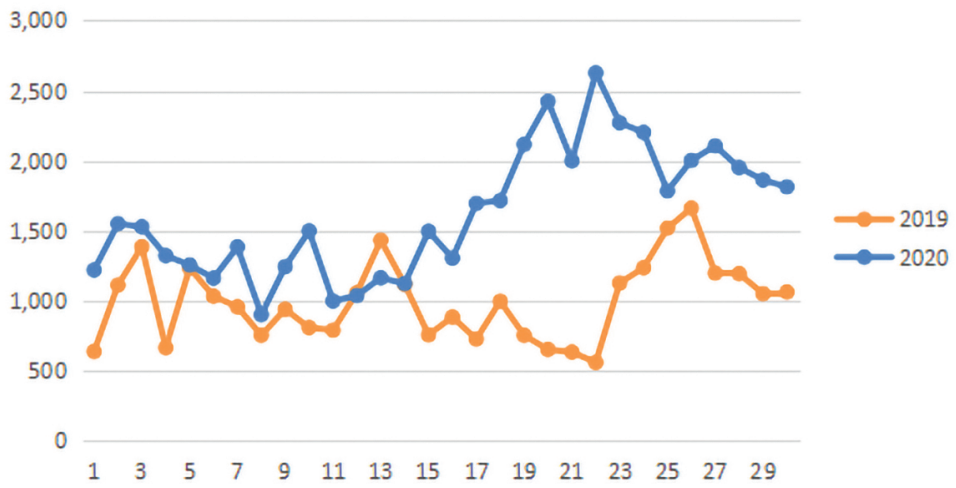

Bron: Corona Crime Change Monitor

Figuur 7 Geregistreerde gevallen van huiselijk geweld in 2019 en 2020, weektotalen, week $1 \mathrm{t} / \mathrm{m} 30$

Huiselijk geweld week 1-30

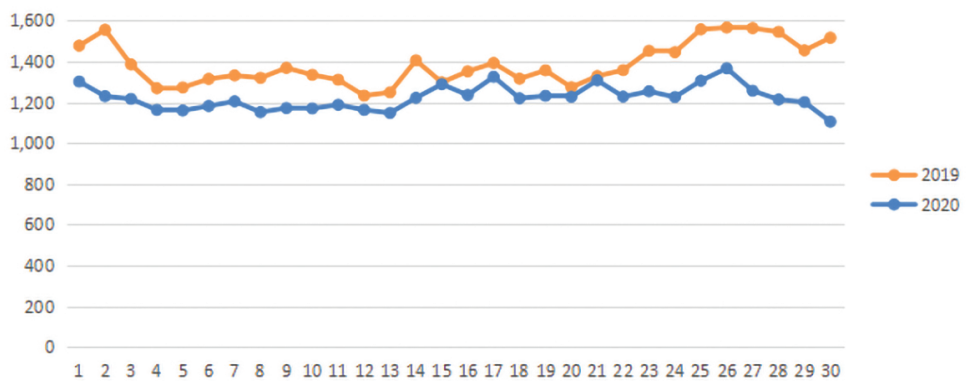

Bron: Corona Crime Change Monitor

Naties waarschuwden dan ook voor een wereldwijde toename van het aantal slachtoffers van huiselijk geweld onder vrouwen en kinderen. ${ }^{32}$

Figuur 7 toont het aantal meldingen van huiselijk geweld bij de politie. We merken hierbij meteen op dat niet alle gevallen van huiselijk geweld bij de politie worden gemeld. De figuur laat, vooral in vergelijking met de voorgaande figuren, een vrij stabiel beeld zien. Er lijken geen grote, schoksgewijze veranderingen te zijn opgetreden in het aantal meldingen van huiselijk geweld. De cijfers voor de afgebeelde periode voor 2020 wijken niet heel sterk af van die voor 2019. Boven- 
dien laten de cijfers voor 2020 ook geen duidelijke ontwikkeling zien. Over de periode week 12-22 liggen de cijfers in 2020 iets lager (7\%) dan in 2019. Of dit ook betekent dat het aantal gevallen daadwerkelijk is afgenomen of dat er eerder sprake is van een slechter functionerend meldingsproces (waarbij slachtoffers bijvoorbeeld niet meer tot aangifte komen), is niet bekend. Het kan ook zijn dat de lockdown wel degelijk tot een groter aantal gevallen van huiselijk geweld heeft geleid, maar de meldingen (nog) niet op gang zijn gekomen, omdat slachtoffers nu bijvoorbeeld meer onder controle staan van hun belagers of omdat meldingen vanuit het onderwijs achterblijven vanwege de tijdelijke scholensluiting. Met de sluiting van scholen is immers een 'toezichthouder' weggevallen. Overigens lijkt de (gedeeltelijke) opening van de basisscholen in week 20 niet tot een duidelijke toename van het aantal meldingen te hebben geleid. Aan de andere kant is het ook mogelijk dat het vele thuisblijven juist tot meer 'toezicht' heeft geleid, bijvoorbeeld wanneer de aanwezigheid van kinderen (tijdelijk) een dempend effect heeft op geweld van mannen tegen vrouwen. Op dit moment zijn dit echter niet meer dan speculaties. We beschikken nu namelijk niet over aanvullende informatie om een en ander verder uit te werken en te toetsen. Wel stellen we vast dat de door ons gebruikte politiecijfers geen stijging laten zien. ${ }^{33}$

\section{Overlast}

Onder overlast wordt hier verstaan overlast die raakt aan onrust of spanning in de wijk, te weten overlast door jeugd, geluidshinder, burenruzies, ruzie/twist en vernieling/vandalisme. Door de anti-coronamaatregelen zijn meer mensen thuis en daardoor zullen zij, vanuit hun woning althans, mogelijk eerder overlast ervaren én veroorzaken. Het veroorzaken van overlast is overigens geen misdrijf en staat dan ook los van het aantal geregistreerde misdrijven.

Er blijkt daadwerkelijk sprake van een forse stijging van het aantal overlastmeldingen (peildatum 1 juni). In week 1-9 van 2020 werden gemiddeld 8.653 overlastmeldingen bij de politie geregistreerd, tegen gemiddeld 8.400 overlastmeldingen in de weken 1-9 van 2019. Echter, vanaf week 12 is een sterke stijging van het aantal overlastmeldingen waar te nemen, met 11.335 overlastmeldingen in week 12 en een piek in week 15 van 15.867 (83\% meer dan het gemiddelde van de weken 1-9). Het totale aantal overlastmeldingen bij de politie ligt over de weken 12-22 in 2020 ruim boven het aantal overlastmeldingen in dezelfde periode in 2019; de toename bedraagt $46 \%$.

33 Een stijging komt evenmin naar voren uit informatie van het Verwey-Jonker Instituut (2020) en het Ministerie van Volksgezondheid, Welzijn en Sport (2020). 


\section{Verdachten en slachtoffers}

Van de 14.340 verdachten die voor een in april 2020 gepleegd delict waren geregistreerd, ${ }^{34}$ was dat voor 140 van hen voor een woninginbraak. ${ }^{35}$ Voor woninginbraken die in de drie voorafgaande aprilmaanden (dus in 2019, 2018 en 2017) werden gepleegd, werden gemiddeld 417 verdachten per aprilmaand genoteerd, een afname van $66 \%$. Het aantal inbraken en het aantal verdachten van inbraak is dus fors afgenomen. ${ }^{36}$ Zijn er aanwijzingen dat het profiel van de verdachte van woninginbraken in coronatijd is gewijzigd?

De gemiddelde verdachte van woninginbraken is ook in april 2020 overwegend man $(93 \%$, enkele procentpunten meer dan in de drie voorafgaande aprilmaanden). Net als in voorgaande jaren komt de verdachte het vaakst (in de helft van de gevallen) uit (zeer) stedelijk gebied en eveneens ongewijzigd is dat de helft van de verdachten tot de laagste opleidingscategorie behoort.

Wel is de verdachte van woninginbraak in de aprilmaand van 2020 vaker tussen de 25 en 45 jaar oud (64\%, ten opzichte van $46 \%$ als gemiddelde van drie voorafgaande aprilmaanden) en valt hij juist minder vaak in de jongere of oudere leeftijdscategorieën. Ook leeft hij wat vaker in een eenpersoons- of eenouderhuishouden (50\% ten opzichte van $37 \%$ ). Een opvallend verschil zien we verder bij uitkeringsafhankelijkheid van verdachten van woninginbraak. In april 2020 heeft 7\% van de verdachten van woninginbraak een WW-uitkering en $36 \%$ een bijstandsuitkering, terwijl de gemiddelde percentages in de drie voorafgaande aprilmaanden liggen op respectievelijk $3 \%$ en $26 \%$. Het ontbreekt nu aan de mogelijkheid om deze verschillen verder te analyseren. Wat echter wel duidelijk is, is dat de genoemde toename sterk afwijkt van de ontwikkeling binnen de totale beroepsbevolking. ${ }^{37}$

Bij de slachtofferpopulatie zien we minder verschillen. Het profiel van het slachtoffer van woninginbraken in april 2020 wijkt niet veel af van dat uit de drie voorafgaande aprilmaanden. Dat profiel ziet er voor de desbetreffende kenmerken als volgt uit: 56\% man; woont in meer dan de helft van de gevallen in (zeer) stedelijk gebied; redelijk gelijkmatig verdeeld over drie opleidingscategorieën; is overwegend tussen de 25 en 65 jaar; woont in iets minder dan helft van de gevallen in een eenpersoons- of eenouderhuishouden; $5 \%$ heeft een WW- en $7 \%$ een bij-

Hier gaat het in tegenstelling tot de analyse van het aantal inbraken (alleen voltooide) om pogingen tot én om voltooide woninginbraken. Niet alle geregistreerde inbraken leiden naar een verdachte.

36 Kanttekening hierbij is dat hoe recenter een delict is gepleegd, hoe kleiner de kans dat het al is opgehelderd en een verdachte bekend is.

37 Voor WW-uitkeringen geldt dat in april 2020 3,2\% van de beroepsbevolking een dergelijke uitkering genoot (bron: UWV). In de drie voorafgaande aprilmaanden was dat gemiddeld 3,6\% (bron: CBS). Voor bijstandsuitkeringen liggen deze percentages op respectievelijk 4,4\% (april 2020) en $4,7 \%$ (gemiddelde van de drie voorafgaande aprilmaanden) (percentages zelf berekend op basis van CBS-gegevens; strikt genomen is vergelijking van het aantal personen met een bijstandsuitkering met de beroepsbevolking niet zuiver, omdat niet alle bijstandsgerechtigden tot de beroepsbevolking behoren). 
standsuitkering. Op geen van deze kenmerken zien we grote verschillen in vergelijking met de drie voorafgaande aprilmaanden.

\section{Conclusie en discussie}

Wat is het bereik en wat zijn de belangrijkste beperkingen van onze analyses? Op het moment van schrijven waren de criminaliteitscijfers tot en met half juli 2020 (net) beschikbaar. De cijfers voor juni en juli zouden nog kunnen worden bijgewerkt (door nagekomen registraties, zie par. 3). Belangrijker is echter dat we beseffen dat een beter beeld ontstaat van de ontwikkeling van de criminaliteit tijdens én na de lockdown wanneer informatie over meer maanden beschikbaar komt. Verder geldt dat wij ons hebben gebaseerd op registratiegegevens. De door de politie geregistreerde misdrijven dekken natuurlijk niet alle gepleegde misdrijven. Een deel van de misdrijven komt namelijk niet in de politieregistraties terecht. Toch laten onze verkennende analyses op enkele hoofdlijnen een duidelijk beeld zien.

Vanaf week 12 (de week die begon op 16 maart) werden er in Nederland verregaande maatregelen ingevoerd om verspreiding van het coronavirus tegen te gaan. Uiteindelijk kwamen deze maatregelen neer op een intelligente lockdown, een min of meer afgedwongen sociale onthouding, sterk verminderde mobiliteit en vooral veel thuisblijven. De totale geregistreerde criminaliteit daalt aanvankelijk fors, maar keert na verloop van tijd weer terug naar een vergelijkbaar niveau als van voor de anti-coronamaatregelen. Vervolgens bekeken we de ontwikkeling voor een aantal verschillende delictsoorten. In de periode week 12-22 neemt het aantal fietsendiefstallen af met een derde, het aantal woninginbraken halveert bijna en zakkenrollerij neemt met driekwart af. Bij babbeltrucs zien we een afname van $7 \%$. Het aantal online delicten is juist sterk toegenomen; in de genoemde periode is er bijna sprake van een verdubbeling van het aantal online misdrijven. Ten slotte blijft de alom gevreesde stijging van huiselijk geweld uit, in ieder geval in de politieregistraties, en laat het aantal overlastmeldingen juist een sterke stijging zien.

De sterkte van de verandering die is opgetreden in het aantal fietsendiefstallen, zakkenrollerij, inbraken en online misdrijven, is opvallend (hoewel vooral bij online delicten wel een voorbehoud geldt vanwege het grillige verloop van de weekcijfers). De lockdown lijkt de gelegenheidsstructuur voor deze vormen van criminaliteit dan ook drastisch te hebben veranderd. Als gevolg van de opgelegde sociale onthouding zijn er minder geschikte doelwitten voor fietsendieven en zakkenrollers; vanwege het thuisblijven is de mobiliteit afgenomen en worden er waarschijnlijk minder fietsen gestald op plaatsen waar deze makkelijk ontvreemd kunnen worden, zoals stations en in binnensteden, en er zijn veel minder, voor zakkenrollers zo aantrekkelijke, drukbezochte plaatsen. Ook staan veel meer woningen (en fietsen) onder actief 'toezicht' dan voorheen en zijn deze niet aantrekkelijk voor inbrekers (respectievelijk dieven), aangezien bewoners nu vaak thuiswerken. De omstandigheden voor daders van online misdrijven zijn door de lockdown juist gunstiger geworden. Vanwege het thuiswerken, het online winke- 
len en boodschappen doen, het online onderhouden van contact met vrienden en familie, en online vermaak, zijn er voor daders van die misdrijven immers meer geschikte doelwitten.

Eerder in dit artikel stipten we kort enkele criminologische, theoretische perspectieven aan. Een gelegenheidstheoretisch perspectief mag dan volgens sommigen plat of theoriearm zijn, het is wel een perspectief waar inmiddels de nodige empirische ondersteuning voor is gevonden. ${ }^{38}$ Ook de uitkomsten van onze verkenning van de criminaliteitscijfers ten tijde van de lockdown, met name de ontwikkeling bij fietsendiefstallen, zakkenrollerij, inbraken en online misdrijven, zijn sterke aanwijzingen dat de gelegenheidsstructuur ertoe doet. Om ontwikkelingen in de criminaliteit te duiden en te verklaren, zijn gelegenheidstheoretische perspectieven dan ook zeer waardevol. Meer beleidsmatig en praktisch betekent dit dat ingrepen in de gelegenheidsstructuur en investeringen in situationele criminaliteitspreventie kansrijke mogelijkheden zijn om criminaliteit te voorkomen.

Oproepen tot 'meer onderzoek' is verre van origineel, maar vanwege de relatief unieke omstandigheden is een dergelijke oproep zeker op zijn plaats. Wanneer voor meer maanden de cijfers beschikbaar zijn, zal onderzoek meer en ook meer robuuste inzichten bieden. $\mathrm{Na}$ verloop van tijd zal het ook mogelijk worden om niet alleen iets te zeggen over de ontwikkelingen tijdens de lockdown, maar ook over veranderingen die zullen optreden tijdens en na verschillende fases van normalisering van het dagelijks leven. Herstellen oude criminaliteitsniveaus zich dan weer? Treedt bij bepaalde delicttypen misschien zelfs een sterke, tijdelijke stijging op, of blijft een dergelijke 'inhaalperiode' (verplaatsing in de tijd) uit?

Verder onderzoek naar huiselijk geweld zal kunnen uitwijzen of de gevreesde stijging op een later moment wel optreedt, bijvoorbeeld als gevolg van meldingen vanuit scholen, die weer volledig zijn opengegaan of als gevolg van acties als 'masker 19'? Of blijft ook dan een stijging uit? Hoe verhouden politieregistraties zich tot cijfers van andere instanties? Hoe verhouden de Nederlandse cijfers zich tot die in het buitenland?

Verder is dader- en slachtofferpopulatie een interessante onderzoeksrichting. De sterke daling bij sommige delicten roept de vraag op of degenen die deze delicten nu nog plegen een echt ander profiel hebben. Is er bijvoorbeeld een harde kern van inbrekers die op bepaalde kenmerken te onderscheiden is van inbrekers die (tijdelijk) zijn afgehaakt? Daders van online misdrijven vormen ook een interessante deelcategorie. Hangt het toegenomen aantal online misdrijven (waarvoor wel het eerder gemaakte voorbehoud geldt) samen met een verplaatsing van het werkveld door daders die voorheen alleen offline actief waren (ook een vorm van verplaatsing)?

Tot slot ligt de grootste meerwaarde mogelijk in het koppelen van antwoorden op kleinere vragen zoals zojuist genoemd, aan grotere, meer wezenlijke vragen. De laatste pakweg twee decennia laat de algemene criminaliteitsontwikkeling in Nederland, maar ook in andere westerse landen, een (zeer) sterke daling zien. Heel veel aandacht heeft het hoe en waarom van die daling tot nu toe nog niet 
gehad, noch in het debat, noch in de wetenschap. ${ }^{39,} 40$ Wat leren inzichten in de ontwikkeling van de criminaliteit tijdens en na de anti-coronamaatregelen ons over de ontwikkeling van criminaliteit in het algemeen?

\section{Referenties}

Ashby, M.P.J., 'Initial evidence on the relationship between the coronavirus pandemic and crime in the United States', Crime Science 2020-9(6).

CBS, www.cbs.nl/nl-nl/dossier/cbs-cijfers-coronacrisis/hoe-beinvloedt-corona-onzemobiliteit, geraadpleegd op 11 september 2020.

Clarke, R.V., 'Opportunity makes the thief. Really? And so what?', Crime Science 2012-1(3).

Cohen, L.E. \& M. Felson, 'Social change and crime rate trends: A routine activity approach', American Sociological Review 1979-44(4), p. 588-608.

Farrell, G., 'Five tests for a theory of the crime drop', Crime Science 2013-2(1), 5; doi: 10.1186/2193-7680-2-5.

Fritz, C.E., 'Disaster', in Contemporary Social Problems, edited by R.K. Merton and R.A. Nisbet. New York: Harcourt 1961, p. 651-694.

Gottfredson, M.R. \& T. Hirschi, A General Theory of Crime. Stanford: Stanford University Press 1990.

Hirschi, T., Causes of Delinquency, Berkeley: University of California Press 1969.

Kleemans, E.R., F. Weerman \& E. Enhus, 'Theoretische vernieuwing in de criminologie', Tijdschrift voor Criminologie 2007-49(3), p. 239-251.

Ministerie van Volksgezondheid, Welzijn en Sport: www.huiselijkgeweld.nl/actueel/ nieuws/2020/04/22/nog-geen-toename-meldingen-bij-veilig-thuis.

Peterman, A., A. Potts, M. O’Donnell, K. Thompson, N. Shah, S. Oertelt-Prigione \& N. van Gelder, Pandemics and Violence Against Women and Children. CGD Working Paper 528, Washington, DC: Center for Global Development 2020. www.cgdev.org/publication/ pandemics-and-violence-against-women-and-children.

Piquero, A.R., N.L. Piquero \& J.R. Riddell, 'Do (sex) crimes increase during the United States Formula 1 grand prix?', Journal of Experimental Criminology 2019; doi: 10.1007/ s1129 2-019-09398-7.

Rokven, J.J., G. Weijters \& A.M. van der Laan, Jeugddelinquentie in de virtuele wereld: Een nieuw type daders of nieuwe mogelijkheden voor traditionele daders?, Den Haag: WODC 2017.

Swaaningen, R. van \& M. Schuilenburg, 'Theoretische vernieuwing in de criminologie', Tijdschrift over Cultuur \& Criminaliteit 2018-8(1), p. 3-18.

Verwey-Jonker Instituut, www.verwey-jonker.nl/nieuws/drie-onderzoeken-naar-huiselijkgeweld-in-tijden-van-corona, geraadpleegd op 16 september 2020.

Waard, J. de, 'Criminology's Dirty Little Secret: Hoe de daling van de criminaliteit bijna geheel voorbijging aan de Nederlandse criminologie', in: C. Bijleveld \& P. van der Laan (red.), Liber Amicorum Gerben Bruinsma, Den Haag: Boom Criminologie, 2017, p. 333-345.

Weitzman, A. \& J.A. Behrman, Disaster, Disruption to Family Life, and Intimate Partner Violence: The Case of the 2010 Earthquake in Haiti, Sociological Science, 2016-3, p. 167-189.

39 In ieder geval niet in vergelijking met de aandacht die veel andere onderwerpen krijgen.

40 De Waard 2017. 
Zahran, S., T. O'Connor Shelley, P. Peek, S.D. Brody, 'Natural Disasters and Social Order: Modeling Crime Outcomes in Florida', International Journal of Mass Emergencies and Disasters 2009-27(1), p. 26-52. 